General, but since March 1994 all acute services have been deltvered in the community or from small purpose-built general hospital units in the city. All that remains on the old Rainhill site is the Regional Secure Unit which was newly built as Rainhill was closing. All other specialised services have been reprovided within the city.

The population of Liverpool has shrunk somewhat but it would surely still rank as a "major metropolitan area'. Perhaps the lack of associated scandal or significant problems in the reprovision of services has led to Liverpool's achievement being overlooked?

M. W. FORTH

North Mersey Community Trust

\section{Increased Consultant job mobility - merit awards}

Sir: A matter has been raised at our meetings concerning the trend to increased consultant job mobility, which may have a detrimental affect upon a colleague's standing when being considered for $\mathbf{C}$ merit awards when changing jobs from one region or one part of the country to another. This may be particularly important with the proposed new arrangements, which will involve local representation and management, although hopefully there will still be room for College and other representation in the local arena.

We think it might be good policy for any consultant moving consultant appointments, particularly from one region to another, to send a copy of their curriculum vitae to the Chairman of their Division for this to be forwarded to the Chairman of the College Division of the region to which they are going. This would enable local College representation to continue to be made and prevent the individual concerned having to start earning a meritorious reputation all over again.

We are sure that there may be other lines of representation and would welcome colleagues' views on this matter, or even a College opinion.

C. E. HYDE

Public Education Officer for The Royal College of Psychiatrists, North West Division

\section{Was Jung a fraud?}

Sir: The press, both here (The Times, 5 June 1995) and in the United States, has made much of an attack on C. G. Jung in a book called The Jung Cult by one Richard Noll, a post-doctoral Fellow at Harvard. Noll accuses Jung of falsifying the details of a piece of evidence which Jung, and his followers, frequently cited in support of his theory of the collective unconscious. It concerned a schizophrenic patient who told Jung that if he stared at the sun with half-closed eyes he would see that the sun had a phallus and that this organ was the origin of the wind. Years later, so Jung said, he came across a Greek text describing an almost identical vision. The patient was a poorly educated man who could not have seen the text, even if he could have understood it, since it was published after his admission to hospital, where no such literature was available.

Noll's researchers have revealed certain discrepancies between Jung's oft repeated account and the facts. These are that the patient was not Jung's but one of Jung's assistants, J. J. Honneger, who two years after reporting the case committed suicide in 1911; the first edition of the book in which the Greek text appeared was published in 1903 (Jung's copy, published in 1910, was a second edition); earlier authors, such as Creuzer and Bachofen, had made references to the solar phallus before that date, and since these were published in German it is possible that the patient could have read them and they could have influenced the content of his hallucination. Noll castigates Jung for not making these facts known and for persisting with his original story, implying that this invalidates Jung's theory.

Although the Solar Phallus Man seems to have been Jung's favourite example to lllustrate his hypothesis of the collective unconscious, it has never seemed a particularly felicitous one. The hallucination is not readily explicable as the result of an archetype of the collective unconscious operating in different individuals living in different places at different times in history. Much more persuastve examples could have been given, such as the behaviour of generations of mothers and children as they work out their personal variations on the basis of the mother-child archetypal programme. To explain Jungs example it is necessary to postulate three archetypal objects (sun, phallus, and wind), an archetypal principle (that of masculine generativity) and an archetypal association between them (the sun's phallus generating the wind). Although such an association is statistically improbable, it is not impossible, but Jung could certainly have found a more persuasive example to support his theory.

In fact, the validity of Jung's hypothesis is in no way dependent upon the case of the Solar Phallus Man. It is striking how many workers in different fields have rediscovered the archetypal hypothesis and proposed it in their own terminology to explain their own observations. For example, the primary concern of Claude Levi-Strauss and the French school of structural anthropology is with the unconscious infrastructures which are held to be responsible for all human customs and institutions; specialists in linguistics maintain that although grammars differ from one another, their basic forms, which Noam Chomsky calls 


\section{CORRESPONDENCE}

their deep structures, are universal (i.e. at the deepest neuropsychic level, there exists a universal or 'archetypal' grammar on which all individual grammars are based); behavioural biologists conceive of innate releasing mechanisms responsible for species, specific patterns of behaviour; and ethologically oriented psychiatrists have begun to study what they call psychobiological response patterns which they hold responsible for the achievement of healthy or unhealthy patterns of adjustment in individual patients in response to variations in their social environment. All these concepts are compatible with the archetypal hypothesis which Jung proposed in the first decade of this century.

The question remains, however, whether Jung deliberately falsified his data. Though Noll is apparently convinced that he did, the evidence he produces is not sufficient to support his conviction. As Noll himself admits, Jung did attribute the case to Honneger in his first published account of it in 1911 (in Wandlungen und Symbole der Libido, Part I). Twenty years later, it is true, Jung claims the case as his own in his essay Die Struktur der Seele in 1930. This is not such a base slip as Noll would imply since Jung was the consultant under whom Honneger worked and therefore the man was technically Jung's patient. Though it is not possible after all this time to form a clear opinion of what occurred, the probability is that the truth is less sinister than Noll would wish to imply. It is undeniable that all his life Jung retained a fondness for the Solar Phallic Man. The case had provided a Eureka experience which strengthened his intuition that beneath our personal intelligence a deeper intelligence is at work - the evolved intelligence of humanity. That Jung may have exaggerated the unlikelihood of Honneger's patient knowing about the Mithraic cult, which specifically celebrated the phallic sun, probably represents nothing more venal than a natural human tendency to improve on a good story. But Jung's theory of archetypes operating through the collective unconscious is in no way dependent upon its veracity.

ANTHONY STEVENS

Fardel Manor, Near Ivybridge, Devon PL21 9HT

\section{Sulpiride and tardive dyskinesia}

Sir: We report on the development of tardive dyskinesia in a 37-year-old lady suffering from paranoid schizophrenia. Her illness was diagnosed in May 1989 and she was commenced on sulpiride $600 \mathrm{mg}$ bid. She remained on sulpiride continuously for the next four years except for a 5 -week period of non-compliance in 1989. The doses ranged from $100 \mathrm{mg}$ daily to $1200 \mathrm{mg}$ daily with an average of $600 \mathrm{mg}$. In January 1993 she was noted to have developed tardive dyskinesia.

The only other significant medication was chlorpromazine: the first course was prescribed in June ' 89 for 21 days, the second during Sept/ Oct ' 90 for 22 days and the third between Dec' 91 and March '92 for 94 days. The average daily dose of the first and third courses was $200 \mathrm{mg}$ daily, and that of the second course $400 \mathrm{mg}$ daily.

Although the exact aetiology of tardive dyskinesia is unknown, newer drugs with more specificity for selective dopamine receptor subtypes are thought to be associated with a lower incidence of extrapyramidal side effects. In this respect sulpiride is only $2-3$ times more potent at D2 than at D3 receptors in comparison with older antipsychotics which may have 10-20 times more affinity for the D2 versus the D3 receptor. However, reports have suggested a causal relationship between tardive dyskinesia and sulpiride (Herraiz, 1991; Miller, 1990). Although this patient was intermittently treated with chlorpromazine, the long-term use of sulpiride and the subsequent development of tardive dyskinesia supports a causal relationship between the two.

Herraiz, J., CANo, A. \& Rogue, J. (1991) Tardive dyskdnesta due to sulpiride. Medicina Clinica (Barcelona), 97, 235236.

MULER, L. G. \& JANKovic, J. (1990) Sulpiride-induced tardive dyskinesia. Movement Disorders, 6, 83-84.

BERNADETTE CULLEN

IAN DALY

St. Loman's Hospital,

Dublin

\section{MRCPsych examinations}

Sir: The MRCPsych examinations, Part $1 \& 2$, are very stressful for candidates and examiners, and bound to remain so (Mindham, 1995)! Concern about the patient management problems stems from the different views of trainers/consultants. Some believe a candidate is allowed to ask a question to be repeated but that writing it down is a bad sign while others encourage a candidate to write a question down if of help.

In the last examination, an examiner in my centre had his vignettes word-processed in very large letters and handed them to candidates while they answered the problems. This examiner prepared well for the examination (not at the last minute!). Top marks' went to him, not only from candidates examined by him, but from others who heard about it nationwide! I encourage other examiners to do likewise.

It may also help if all trainers/consultants have regular group updates, apart from information sent to them from the College, to discuss the examinations and ways to help their juniors. This 